Western North American Naturalist 70(1), (C) 2010, pp. 48-54

\title{
DENNING CHRONOLOGY OF BLACK BEARS IN EASTERN ROCKY MOUNTAIN NATIONAL PARK, COLORADO
}

\author{
Roger A. Baldwin ${ }^{1,2}$ and Louis C. Bender 3,4
}

\begin{abstract}
Understanding factors influencing the timing of den entrance and emergence of black bears (Ursus americanus) provides insight for bear management. We determined den entrance and emergence dates for bears in Rocky Mountain National Park (RMNP) and related these dates to vegetative productivity, weather, habitat, and demographic factors to assess the influence of these factors on denning chronology. Date of den entrance was most strongly influenced by age class, precipitation, and proportion of human-use areas in annual home ranges. Den entrance was typically later for adult bears during wetter years and when annual home ranges contained a greater proportion of humanuse areas. Sex and presence of human-use areas were most strongly related to den emergence. Male bears typically emerged from dens before females, and bears emerged from dens earlier when human-use areas composed a greater proportion of annual home ranges. Collectively, our results suggest that denning behavior of black bears in RMNP was strongly influenced by presence of human-use areas, likely because of foods associated with such areas. Managers of black bears in RMNP can use precipitation to predict relative dates of den entrance, thereby allowing for more efficient strategies to combat potentially negative human-black bear encounters.
\end{abstract}

Key words: black bear, Colorado, denning chronology, NDVI, precipitation, temperature, Ursus americanus.

Hibernation is a critical component of the black bear (Ursus americanus) life cycle throughout much of temperate North America, with dens providing shelter and protection during this period of winter lethargy (Rogers 1987, Beck 1991). Understanding the factors that influence the timing and duration of denning thus provides insight for bear management. It is generally accepted that the reductions in both photoperiod and temperature that are associated with late autumn and early winter provide the initial cues for denning (Johnson and Pelton 1980, Schooley et al. 1994). However, the ultimate factor influencing den entrance and emergence dates likely relates to energy balance of the individual bear (Lindzey and Meslow 1976, Schooley et al. 1994). As food becomes scarce, a negative energy balance occurs, and because it is no longer advantageous to continue foraging, bears den. Therefore, in much of the black bear's range, food availability is a strong predictor of the denning period (Johnson and Pelton 1980, Beecham et al. 1983, Schooley et al. 1994, Costello et al. 2001).

Reliable measures of food availability are often unavailable. However, climatic data such as temperature and precipitation have been correlated to annual net primary productivity and length of the vegetative growing season (Jobbágy et al. 2002, Kerkhoff et al. 2005). Climatic data are readily available and provide a possible alternative for assessing the relationship between food availability and denning period. Similarly, measures of the normalized difference vegetation index (NDVI) from remote-sensor data can provide measures of greenness on the landscape. These measures correlate well with aboveground net primary production of vegetative communities (Hobbs 1995, Pettorelli et al. 2005). NDVI values have been used for a variety of objectives, from predicting suitable habitats for grizzly bears (Ursus arctos; Mace et al. 1999) to relating habitat selection to ecosystem functioning in grizzly bears (Wiegand et al. 2008). Therefore, NDVI may also be an effective tool for explaining variability in denning chronology, although NDVI may not completely represent food availability, given that black bears' use of berries and insects may not be represented in greenness scores (Wiegand et al. 2008). Additionally, anthropogenic food sources associated with human-use areas can supplement bear

\footnotetext{
${ }^{1}$ Department of Animal and Range Sciences, New Mexico State University, Las Cruces, NM 88003.

${ }_{2}^{2}$ Present address: U.C. Kearney Agricultural Center, 9240 S. Riverbend Ave., Parlier, CA 93648. E-mail: rbaldwin@uckac.edu

${ }^{3}$ U.S. Geological Survey, New Mexico Cooperative Fish and Wildlife Research Unit, Box 30003 MSC 4901, Las Cruces, NM 88003.

4Present address: Department of Extension Animal Sciences and Natural Resources, New Mexico State University, Las Cruces, NM 88003.
} 
diets, leading to later dates of den entrance (Beckmann and Berger 2003a).

The timing of den emergence is also influenced by multiple factors, including air temperature (Lindzey and Meslow 1976, O’Pezio et al. 1983, Kolenosky and Strathearn 1987, Rogers 1987) and sex and age class of individuals (Novick et al. 1981, LeCount 1983, Rogers 1987). Consequently, the timing varies substantially across locations. As with den entrance, availability of anthropogenic foods may also influence den emergence. Abundant highenergy food sources are typically rare to nonexistent during early spring in much of the black bear's range (Pelton 2003), though anthropogenic food sources are often available year-round (Beckmann and Berger 2003a). Therefore, individuals with ready access to anthropogenic foods may leave dens earlier than those with less access, given the lack of alternative food sources.

The black bear population in Rocky Mountain National Park (RMNP), Colorado, is very low density $\left(1.35\right.$ bears $\cdot 100 \mathrm{~km}^{-2}$; Baldwin 2008) and exists in an extreme climate, potentially limiting its viability. Because denning is a critical aspect in the life history of black bears in extreme climates such as RMNP, we determined proximate factors influencing denning chronology to provide information for managing denning habitats. Knowing what factors influence denning chronology, especially if the factors are related to food, allows staff to manage habitat attributes important to bear energetics and thus bear reproductive productivity in RMNP. Our objective was to determine which factors best predict den entrance and den emergence of bears in RMNP.

\section{Study Area}

RMNP is a $1080-\mathrm{km}^{2}$ bioreserve located in the Rocky Mountain Front Range of north central Colorado. Topography in RMNP was shaped by glaciers and consists of high mountainous peaks interspersed with small subalpine meadows, lakes, streams, glaciers, and tundra at higher elevations. Elevations range from 2400 to $4345 \mathrm{~m}$. The Continental Divide bisects RMNP, creating different climatic patterns and vegetation types from east to west. Eastern RMNP is drier, with precipitation averaging $35.1 \mathrm{~cm}$ just outside the park boundary in the town of Estes Park, Colorado; western
RMNP was not sampled for this investigation. Seventy-five percent of annual precipitation falls from April to September. In Estes Park, mean daily high temperatures range from 7.2 ${ }^{\circ} \mathrm{C}$ in February to $27.8^{\circ} \mathrm{C}$ in July.

Vegetation in RMNP consists of $>700$ plant species. Montane forests on the eastern slope include lodgepole pine (Pinus contorta) and aspen (Populus tremuloides), with drier sites often dominated by ponderosa pine (Pinus ponderosa) and Douglas-fir (Psuedotsuga menziesii). Subalpine habitats are dominated by Engelmann spruce (Picea engelmannii) and subalpine fir (Abies bifolia) with limber pine (Pinus flexilis) occasionally present. Elevations above timberline (approximately $3500 \mathrm{~m}$ ) are dominated by tundra and bare rock. Below tree line, wetland and riparian areas are composed of a variety of species but are dominated by dense stands of spruce-fir and aspen in forested areas (Salas et al. 2005).

\section{Methods}

We used modified Aldrich foot snares and a culvert trap to capture bears from 2003 to 2006. We immobilized captured bears with a 5:1 mixture of ketamine hydrochloride (approximately $7.4 \mathrm{mg} \cdot \mathrm{kg}^{-1}$ body mass) and xylazine hydrochloride (approximately $1.3 \mathrm{mg} \cdot \mathrm{kg}^{-1}$ body mass) and fit them with radio-collars to facilitate location of den sites. We also classified bears by sex and age (subadult vs. adult). Adult females were differentiated from subadult females based on known age, nipple size, and nipple coloration (Beck 1991, Brooks and McRoberts 1997), while adult males were differentiated from subadult males by large size, obvious staining of teeth, and descended testicles (Beck 1991, Garshelis and Hellgren 1994).

Starting on 1 October, we typically located bears $\geq 2$ times weekly to determine date of den entrance; bear locations were similarly checked starting on 1 March to determine date of den emergence. We assigned an approximate date of den entrance equal to the median date between the last known date of activity and the first known date of denning and vice versa for den emergence.

We obtained total precipitation $(\mathrm{cm})$ values recorded from 1 April to 30 September in Estes Park (http://weather-source.com) and at 2 additional sites in RMNP (http://www. wcc.nrcs.usda.gov/snow). We used precipitation 
recorded over this time frame as a surrogate for vegetative productivity for each respective year, as precipitation is closely tied to annual net primary productivity (Jobbágy et al. 2002, Kerkhoff et al. 2005).

We also used NDVI as a measure of vegetative productivity, with higher values indicating greener vegetation (Weiss et al. 2004). We used NDVI values derived from moderateresolution imaging spectroradiometry (MODIS; http://pekko.geog.umd.edu/usda/test). MODIS NDVI observations were available at 250-m resolution for 16-day periods during the time frame of the study. For analysis, we calculated mean NDVI values (ARCGIS 9.2, Environmental Systems Research Institute, Redlands, CA) for eastern RMNP for the annual vegetative growing season (9 June-30 September) to quantify vegetative productivity during the entire growing season. Additionally, given the potentially high difference in NDVI values associated with different cover types (Weiss et al. 2004), we combined all cover types into 4 classes: closed (e.g., spruce/fir, lodgepole pine, aspen) and open (e.g., ponderosa and limber pine) forest and low-elevation (e.g., low-elevation meadows, montane shrublands) and high-elevation (e.g., tundra, high-elevation meadows, glaciers, talus) open habitats. We averaged NDVI values for each class of cover type by year. Occasionally, NDVI values obtained for a specific 16-day period had substantial portions obscured due to cloud cover. In these situations, we excluded such 16-day periods from mean-value calculations. We averaged NDVI values over eastern RMNP to estimate plant productivity at the same resolution as precipitation data.

We calculated proportion of each bear's annual (95\% minimum convex polygon) home range composed of human-use sites and used ARCGIS 9.2 to assess the potential influence of anthropogenic food sources on denning chronology (Beckmann and Berger 2003a). Human-use areas were defined as buffered areas within $400 \mathrm{~m}$ of roads, trails, campsites, and urban sites. This distance was selected given that approximately half $(51 \%)$ of all bear activity locations from a previous study on black bears in RMNP (1984-1991) were found within $400 \mathrm{~m}$ of human-use sites (L. Zeigenfuss, United States Geological Survey, unpublished report, 2001). Also, this distance provided a realistic buffer to assess potential human-use influences on bear activity. Baldwin (2008) found a strong correlation $(r=$ 0.87 ) between proportion of home ranges composed of human-use areas and percent body fat of female bears in RMNP (indicating greater resource quality, quantity, or both, in human-use areas) as well as a high prevalence (14.2\% of scats) of anthropogenic foods in bear scats. These findings gave us reason to believe that higher availability of human-use areas within home ranges accurately reflects increased consumption of anthropogenic foods.

We correlated (Ramsey and Shafer 1997) surrogates of food productivity (proportion of annual home ranges composed of human-use areas, total precipitation, and NDVI for growing season) and demographics (sex and age class) to date of den entrance (Julian date) to assess the influence of these factors on denning chronology. We treated sex (female $=0$, male $=1$ ) and age class (adult $=0$, subadult $=1$ ) as indicator variables in the analyses (Ramsey and Shafer 1997). Finally, we used backward-selection multiple regression (Ramsey and Shafer 1997) to determine the best model predictive of den entrance, using only the significantly correlated variables above. We considered all correlations and regressions to be significant at $\alpha=0.10$. We assessed potential outliers using residual plots (Ramsey and Schafer 1997).

We similarly used correlations and linear regression (Ramsey and Shafer 1997) to relate sex, age class, temperature $\left({ }^{\circ} \mathrm{C}\right)$, and proportion of annual home ranges composed of human-use areas to dates of den emergence. Temperature represented the mean maximum temperature for March-April and was recorded at the same locations as those used for precipitation recordings in den entrance analyses. We selected this time frame to represent temperature immediately prior to and subsequent to typical den emergence (i.e., mid- to late April). We analyzed data for den emergence the same way as data for den entrance.

\section{RESULTS}

From 2003 to 2006, we recorded 22 (5 adult male, 1 subadult male, 10 adult female, 6 subadult female) denning occurrences for 8 individual bears ( 2 adult males, 1 subadult male, 4 adult females, and 2 subadult females; note that these do not sum to 8 , given that 
TABLE 1. Results of multiple linear regression models relating den entrance and emergence dates of black bears to demographic and weather variables, vegetative productivity surrogates, and human-use components of bear home ranges in Rocky Mountain National Park, Colorado, 2003-2006.

\begin{tabular}{|c|c|c|c|c|c|c|c|c|}
\hline Behavior & $F$ & $P$ & $R^{2}$ & Variable & $t$ & $P$ & $\beta$ & SE \\
\hline \multirow[t]{3}{*}{ Entrance } & 14.0 & $<0.001$ & 0.725 & Age class & -3.9 & 0.001 & -16.489 & 4.261 \\
\hline & & & & Precipitation & 3.4 & 0.004 & 0.747 & 0.219 \\
\hline & & & & Annual human use & 1.7 & 0.109 & 29.203 & 17.185 \\
\hline \multirow[t]{2}{*}{ Emergence } & 8.3 & 0.006 & 0.580 & Annual human use $\mathrm{e}^{\mathrm{a}}$ & -3.2 & 0.008 & -53.309 & 16.845 \\
\hline & & & & Sex & -2.8 & 0.017 & -14.098 & 5.111 \\
\hline
\end{tabular}

annual human use $=$ proportion of annual home ranges composed of human-use areas.

1 female became an adult during this study). Dates of den entrance ranged from 12 October to 27 November, while den emergence dates ranged from 30 March to 12 May. Given the small number of bears present in eastern RMNP (14-16 bears; Baldwin 2008), repeated measuring of individuals was unavoidable. Nonetheless, repeated sampling of $\geq 50 \%$ of the population should provide meaningful insight into factors influencing denning chronology for this population. Moreover, bears often catabolize all fat and a substantial portion of their lean muscle tissue during their annual hibernation (e.g., Atkinson et al. 1996). Consequently, they are almost entirely dependent on the nutritional quality of their spring-autumn ranges to accrue sufficient reserves for hibernation. Because decisions on denning chronology depend upon annual variation in quality of ranges, each year is an independent event with respect to resource availability within home ranges and accrual of body condition.

Age class $\left(t_{18}=-3.0, P=0.007, r=0.58\right)$, proportion of human-use areas $\left(t_{18}=3.0, P=\right.$ $0.008, r=0.58)$, and total precipitation $\left(t_{18}=\right.$ 2.8, $P=0.013, r=0.55)$ were related to date of den entrance, whereas no NDVI values were significant $\left(t_{18} \leq|1.6|, P \geq 0.124, r \leq 0.34\right)$. The model including age class, precipitation, and proportion of human-use areas (Table 1) best fit den-entrance data $\left(F_{3,16}=14.0, P<\right.$ $\left.0.001, R^{2}=0.725\right)$ for bears and indicated that denning occurred earlier for subadult bears and during drier years (Table 1). The effect of human-use areas was not significant, although bears in annual home ranges with greater proportions of human-use areas tended to den later (Table 1). This model excluded 2 outlier dates, both from one large adult female in very good condition (37\% body fat in 2005, $45 \%$ body fat in 2006; Baldwin 2008); bears in very high condition often den earliest (Rogers 1987), contrary to the normal progression of den entrance (i.e., bears in poor condition denning earlier).

Proportion of human-use areas $\left(t_{13}=-2.4\right.$, $P=0.030, r=0.56)$ and $\operatorname{sex}\left(t_{13}=-2.0, P=\right.$ $0.071, r=0.48)$ were correlated with den emergence, whereas age class $t_{13}=0.8, P=$ $0.453, r=0.210)$ and temperature $\left(t_{13}=1.6\right.$, $P=0.125, r=0.41)$ were not. Den emergence $\left(F_{2,12}=8.3, P=0.006, R^{2}=0.580\right)$ was related to sex and the proportion of annual home ranges composed of human-use areas: males and a greater proportion of human-use areas were associated with earlier emergence dates (Table 1).

\section{Discussion}

Factors that influence denning chronology of black bears vary substantially depending on the population but typically have been related to food availability (Johnson and Pelton 1980, Beecham et al. 1983, Schooley et al. 1994, Costello et al. 2001). Likewise, precipitation, a surrogate for vegetative productivity, was associated with den entrance in RMNP. Models predicted later den entrance during years with greater precipitation (Table 1), suggesting that greater forage productivity may lead to later denning dates. The comparatively weaker association of den entrance with NDVI may be influenced by an incomplete representation in NDVI values of many important food sources for bears, such as berries and insects, that may not be represented in greenness scores (Wiegand et al. 2008). Therefore, although NDVI likely indexes food productivity for bears to some degree, foods not directly related to photosynthetic activity of plants may be poorly represented. Consequently, a climatic surrogate of vegetative productivity (i.e., precipitation) performed better for estimating den entrance.

In contrast to some other studies (e.g., Kolenosky and Strathearn 1987, Smith et al. 
1994), we observed earlier denning by subadults (Table 1). Subadult females in our population were in poorer condition than adults during early hibernation (adult body fat $=$ $38 \%$, subadult body fat $=24 \%$; Baldwin 2008); oftentimes bears in poor condition den later than those in good condition (Carpenter 1973, Hamilton and Marchinton 1980). However, dominant bears can act as despots by excluding others from preferred foraging locations, resulting in later den entrance for dominant individuals (Beckmann and Berger 2003b). In support of this, we observed later denning by bears with a greater proportion of human-use areas within their annual home ranges (Table 1), similar to results observed in the Lake Tahoe region of Nevada (Beckmann and Berger 2003a). Many adult bears in RMNP and Lake Tahoe readily consumed anthropogenic foods, leading to high condition levels (Beckmann and Berger 2003a, Baldwin 2008). Therefore, exclusion of subadults from high-quality food patches (typically anthropogenic food sources) may explain the earlier denning of subadults. Also, typical high-quality autumn foods of black bears (i.e., hard and soft mast; Pelton 2003) are rare in RMNP (Baldwin 2008), and thus subadults are unlikely to benefit energetically from continued foraging activities. The exception to this relationship was one female who was in particularly good condition during the last 2 years of the study ( $37 \%$ body fat in 2005 , $45 \%$ body fat in 2006; Baldwin 2008). Rogers (1987) suggested that bears in extremely high condition may den particularly early, given their little need to accrue additional fat stores. Our findings support this idea, although this relationship should be explored further to clarify our results.

Sex did not influence timing of den entrance in RMNP, although male bears often den later than females (O'Pezio et al. 1983, Beck 1991, Smith et al. 1994). This lack of statistical significance might have been due to the few observed denning occasions by males, as males had a later mean den entrance date than females in RMNP (day 321 for males, $\mathrm{SE}=5, n=6$; day 312 for females, $\mathrm{SE}=4, n=16$ ). However, sex did influence den emergence. Males emerged before females, which is similar to results from other studies (Kolenosky and Strathearn 1987, Smith et al. 1994, Gaines 2003).

Temperature has been implicated as a cue for den emergence in other black bear populations. Often bears emerge earlier from dens during warmer years because warm weather melts snow and can cause flooding of dens (Kolenosky and Strathearn 1987, Rogers 1987). The lack of a temperature effect in our study may have been influenced by the early emergence of bears having annual home ranges in RMNP with high proportions of human-use areas, as such areas provide consistent and abundant food (Beckmann and Berger 2003a).

\section{Management Implications}

Human influences and plant productivity (as assessed by climatic surrogates) appeared to affect denning chronology of black bears in RMNP, with these likely food-driven effects further influenced by sex and age of bears. Results from an additional study in RMNP indicated a shift in den sites over the last 15-20 years from higher-elevation wildland areas to lower-elevation sites closer to human-use areas, likely because of attempts by bears to access the resources associated with these areas (Baldwin and Bender 2008). Because natural foods, particularly foods bears depend on for lipogenesis in autumn (i.e., hard mast), are scarce in RMNP, managers may have few options to reverse trends of altered denning chronology or of bears denning closer to human-use areas. However, knowing when the potential for conflict is high will allow managers to prepare for increased encounters with bears, thereby allowing for more efficient allocation of management resources to combat these potential conflicts (Zack et al. 2003). For example, people are often less vigilant in securing garbage, bird feeders, and other food-related items when they don't expect bears to be active. Therefore, during wet years, RMNP staff could inform park visitors and local residents that bears will likely remain active later in the year than usual and that people should continue to secure potential bear foods in an appropriate manner. This effort may be particularly important over the next $5-10$ years, as the potential for human-bear conflict will increase in RMNP if the black bear population continues to grow at its current rate (Baldwin and Bender 2009). Such actions could mitigate potential human-bear conflicts.

\section{ACKNOWLEDGMENTS}

This research was funded by Rocky Mountain National Park and the United States 
Geological Survey. The New Mexico State University Agricultural Experiment Station provided additional financial assistance. S. Graham, B. Hoenes, L. Polson, M. Polson, and K. Snow provided valuable field assistance.

\section{Literature Cited}

Atkinson, S.N., R.A. Nelson, and M.A. Ramsay. 1996. Changes in the body composition of fasting polar bears (Ursus maritimus): the effect of relative fatness on protein conservation. Physiological Zoology 69:304-316.

Baldwin, R.A. 2008. Population demographics, habitat utilization, critical habitats, and condition of black bears at Rocky Mountain National Park. Doctoral dissertation, New Mexico State University, Las Cruces, NM.

BALDWIn, R.A., AND L.C. BENDER. 2008. Den-site characteristics of black bears in Rocky Mountain National Park, Colorado. Journal of Wildlife Management 72:1717-1724.

2009. Survival, productivity, and trends of a lowdensity black bear population in Rocky Mountain National Park, Colorado. Human-Wildlife Conflicts 3:271-281.

BECK, T.D.I. 1991. Black bears of west-central Colorado. Technical Publication Number 39, Colorado Division of Wildlife, Fort Collins, CO.

Beckmann, J.P., AND J. Berger. 2003a. Rapid ecological and behavioural changes in carnivores: the responses of black bears (Ursus americanus) to altered food. Journal of Zoology 261:207-212.

$2003 \mathrm{~b}$. Using black bears to test ideal-free distribution models experimentally. Journal of Mammalogy 84:594-606.

Beecham, J.J., D.G. Reynolds, and M.G. Hornocker. 1983. Black bear denning activities and den characteristics in west-central Idaho. International Conference on Bear Research and Management 5:79-86.

Brooks, R.T., and R. McRoberts. 1997. Nipple dimensions and reproductive status of northeastern Minnesota female black bears (Ursus americanus). American Midland Naturalist 137:178-182.

Carpenter, M. 1973. The black bear in Virginia. Virginia Commission of Game and Inland Fisheries, Richmond, VA.

Costello, C.M., D.E. Jones, K.A. Green-Hammond, R.M. Inman, K.H. Inman, B.C. Thompson, R.A. Deitner, AND H.B. QuigLey. 2001. A study of black bear ecology in New Mexico with models for population dynamics and habitat suitability. Final Report, Federal Aid in Wildlife Restoration Project W-131-R, New Mexico Department of Game and Fish, Santa Fe, NM.

GAINES, W.L. 2003. Black bear, Ursus americanus, denning chronology and den site selection in the northeastern Cascades of Washington. Canadian FieldNaturalist 117:626-633.

Garshelis, D.L., AND E.C. Hellgren. 1994. Variation in reproductive biology of male black bears. Journal of Mammalogy 75:175-188.

Hamilton, R.J., and R.L. Marchinton. 1980. Denning and related activities of black bears in the coastal plain of North Carolina. International Conference of Bear Research and Management 4:121-126.

Hobвs, T.J. 1995. The use of NOAA-AVHRR NDVI data to assess herbage production in the arid rangelands of Central Australia. International Journal of Remote Sensing 16:1289-1302.

Jobbágy, E.G., O.E. Sala, and J.M. Paruelo. 2002. Patterns and controls of primary production in the Patagonian steppe: a remote sensing approach. Ecology 83:307-319.

Johnson, K.G., And M.R. Pelton. 1980. Environmental relationships and the denning period of black bears in Tennessee. Journal of Mammalogy 61:653-660.

Kerkhoff, A.J., B.J. Enquist, J.J. Elser, and W.F. Fagan. 2005. Plant allometry, stoichiometry, and the temperature-dependence of primary productivity. Global Ecology and Biogeography 14:585-598.

Kolenosky, G.B., and S.M. Strathearn. 1987. Winter denning of black bears in east-central Ontario. International Conference on Bear Research and Management 7:305-316.

LeCount, A.L. 1983. Denning ecology of black bears in central Arizona. International Conference on Bear Research and Management 5:71-78.

Lindzey, F.G., AND E.C. MEsLow. 1976. Winter dormancy in black bears in southwestern Washington. Journal of Wildlife Management 40:408-415.

Mace, R.D., J.S. Waller, T.L. Manley, K. Ake, and W.T. WiTTINGER. 1999. Landscape evaluation of grizzly bear habitat in western Montana. Conservation Biology 13:367-377.

Novick, H.J., J.M. Siperek, And G.R. Stewart. 1981. Denning characteristics of black bears, Ursus americanus, in the San Bernardino Mountains of southern California. California Fish and Game 67:52-61.

O’Pezio, J., S.H. Clarke, And C. Hackford. 1983. Chronology of black bear denning in the Catskill region of New York. International Conference on Bear Research and Management 5:87-94.

Pelton, M.R. 2003. Black bear (Ursus americanus). Pages 547-555 in G.A. Feldhamer, B.C. Thompson, and J.A. Chapman, editors, Wild mammals of North America: biology, management, and conservation. Second edition, revised. Johns Hopkins University Press, Baltimore, MD.

Pettorelli, N., J.O. Vik, A. Mrsterud, J.-M. Gaillard, C.J. Tucker, and N.C. Stenseth. 2005. Using the satellite-derived NDVI to assess ecological responses to environmental change. Trends in Ecology and Evolution 20:503-510.

Ramsey, F.L., AND D.W. SChafer. 1997. The statistical sleuth: a course in methods of data analysis. Duxbury Press, Belmont, CA.

Rogers, L.L. 1987. Effects of food supply and kinship on social behavior, movements, and population growth of black bears in northwestern Minnesota. Wildlife Monographs 97.

Salas, D., J. Stevens, And K. Schulz. 2005. Rocky Mountain National Park, Colorado 2001-2005 vegetation classification and mapping. Final Report, Technical Memorandum 8260-05-02, Remote Sensing and GIS Group, Technical Service Center, Bureau of Reclamation, Denver, CO.

Schooley, R.L., C.R. McLaughlin, G.J. Matula JR., and W.B. Krohn. 1994. Denning chronology of female black bears: effects of food, weather, and reproduction. Journal of Mammalogy 75:466-477.

Smith, M.E., J.L. Hechtel, And E.H. Follmann. 1994. Black bear denning ecology in interior Alaska. International Conference on Bear Research and Management 9:513-522. 
Weiss, J.L., D.S. Gutzler, J.E. Allred Coonrod, And C.N. DAнм. 2004. Long-term vegetation monitoring with NDVI in a diverse semi-arid setting, central New Mexico, USA. Journal of Arid Environments 58:249-272.

Wiegand, T., J. Naves, M.F. Garbulsky, and N. FernánDEZ. 2008. Animal habitat quality and ecosystem functioning exploring seasonal patterns using NDVI. Ecological Monographs 78:87-103.
Zack, C.S., B.T. Milne, And W.C. Dunn. 2003. Southern oscillation index as an indicator of encounters between humans and black bears in New Mexico. Wildlife Society Bulletin 31:517-520.

Received 1 December 2008 Accepted 2 September 2009 